\title{
Study of Haematological Parameters of Crossbred Cows during Peripartum Period
}

\author{
Krupa R. Joshi, M.M. Pathan*, S.P. Madhira, A.M. Pande and Dhara D. Dhusa \\ Department of Veterinary Physiology \& Biochemistry, College of Veterinary Science \& \\ Animal Husbandry, AAU, Anand, India
}

\begin{tabular}{|l|}
\hline Key w o r d s \\
Cow, Haematoloy, \\
Peripartum period
\end{tabular}

A B S T R A C T

A study was carried to observe the changes in the Haematological parameters such as Total Erythrocyte count (TEC), Total Leukocyte Count (TLC), Haemoglobin (Hb), Packed Cell Volume (PCV), Mean Corpuscular Volume (MCV), Mean Corpuscular Haemoglobin $(\mathrm{MCH})$, Mean Corpuscular Haemoglobin Concentration (MCHC), Total Platelet count and Differential Leukocytes count (DLC) of crossbred cows Karan Fries (KF) (Holstein Fresian $\times$ Kankrej) cows during transition period. Blood samples were collected from the jugular vein of the selected animals on $-30,-15,-7,0,+7,+15,+30$ days with respect to expected date of calving. TEC and $\mathrm{Hb}$ non-significantly increased on the day of calving. A continuous non-significant reduction observed till 15 day after calving as compared to the day of calving. Highest TLC and PCV value observed on 7th day before calving. Then non-significant reduction was observed on the day of calving. MCV and MCH was increased significantly $(\mathrm{p}<0.05)$ on the day of calving as compared to 30 day before calving whereas, highest MCHC observed on 15 day before calving and significantly $(p<0.05)$ decreased on the day of calving. Lymphocyte count significantly $(p<0.05)$ reduced on the day of calving as compare of 30 days before calving. Neutrophil count observed non-significantly decreased on the day of calving as compared to 3 days before calving. Thereafter, significant $(\mathrm{p}<0.05)$ reduction was observed till 30 day after calving.

\section{Introduction}

Transition period i.e. the dry period 3 week before to 3 week after parturition is peripartum period and generally accepted as the most critical period with respect to mammary health in dairy cow. In this critical period the mammary gland undergoes marked haematological, cellular and immunomodulatory changes to accommodate involution, to prepare for parturition, to withstand the stress of parturition, to transform colostrum into milk, and then for the attainment of peak milk production. These periods also coincide with impaired lymphocyte and neutrophil function (Kehrli et al., 1989). The erythrocyte parameters and total and differential leucocyte counts (DLC) are also affected (Klinkon, 1992) regarding the mammary gland, extensive influx of neutrophils into the colostrums and milk occurs around calving and during the first week after calving (Guidry et al., 1976). Laboratory testing is an important tool that 
helps practitioners monitor transition cow health at the individual and herd levels. Metabolic profile testing (MPT) (Rowlands, 1980) refers to the use of tests for diagnosis of subclinical, nutritional and metabolic disease in dairy cows on a herd basis. The knowledge of hematological values is useful in diagnosing various pathological and metabolic disorders. Therefore the present study was designed to investigate various hematological changes occurring in crossbred cows during peripartum period.

\section{Materials and Methods}

Six crossbred cows (Holstein Fresian $x$ Kankrej) were selected in their advance stage of gestation from the Livestock Farm Complex (LFC), Department of Livestock Production Management at College of Veterinary Science and A.H., Anand. The experimental animals were reared in semiopen housing system which is made up of concrete floor under asbestos roofed housing system constructed east west direction and well covered with trees. From each experimental animal $9 \mathrm{ml}$ Blood was drawn in sterile heparinized vacutainer tube from jugular vein puncture, posing minimum disturbance to the animal during collection on days $-30,-15,-7$ and -3 before calving, on the day of calving and on days 3, 7, 15 and 30 after calving. Immediately after collection the samples were transported to the laboratory over ice for further processing. The samples were analyzed for Haematological parameters such as Total Erythrocyte count (TEC), Total Leukocyte Count (TLC), Haemoglobin ( $\mathrm{Hb}$ ), Packed Cell Volume (PCV), Mean Corpuscular Volume (MCV), Mean Corpuscular Haemoglobin (MCH), Mean Corpuscular Haemoglobin Concentration (MCHC), Total Platelet count and Differential Leukocytes count (DLC) using automated haematology analyzer (Make Mindrey; model BC 2800). The data were analyzed using two ways ANOVA. The results were expressed as mean $( \pm$ SEM). Significance was tested by Duncan's New Multiple Range Test (DNMRT) at Department of Agricultural Statistics, Anand Agricultural University, Anand (Snedecor and Cocharan, 1994).

\section{Results and Discussion}

We have analyzed the blood samples for various haematological parameters and the results obtained from the analysis are presented in table 1 and 2 . TEC $\left(x_{10} / \mu \mathrm{L}\right)$ of crossbred cattle ranged from $6.94 \pm 0.08$ to $6.21 \pm 0.30$ and they have significant $(p<0.05)$ differences. The TEC increased nonsignificantly on 7 days before calving as compared to 15 and 30 days before calving. Then significant $(\mathrm{p}<0.05)$ reduction was observed on 3 days before calving. Junid and Krad, (1987) observed highest TEC count at 3-5 h after parturition. Patel et al., (2017) reported that significantly increased $(\mathrm{P}<0.05)$ value of TEC on day of calving in KF cows which might be due to erythropoiesis and slow destruction of erythrocytes during transition period. However, the TEC level decreased to prepartum level after one week of calving. The present study is also similar with them.

TLC $\left(\times 10^{3} / \mu \mathrm{L}\right)$ ranged from $10.20 \pm 1.29$ to $7.62 \pm 0.99$ and they have significant $(\mathrm{P}<0.05)$ differences. The TLC was increased significantly $(\mathrm{P}<0.05)$ on 7 days before calving as compared to 30 days before calving. There after TLC was decreased Nonsignificantly on 3 days before calving. A nonsignificant increase in TLC was observed on the day of calving as compared to 7 days before calving but significant $(\mathrm{p}<0.05)$ with 15 and 30 days before calving. After calving TLC reduced non-significantly till 30 days postpartum. Pomsel, (1980) also recorded a significantly higher TLC at parturition in comparison to the second week after parturition. Schalm and Jain, (1986) reported 
that pregnancy did not markedly affect the TLC. An increase in TLC around calving is mediated by an antepartum rise in cortisol levels (Hussain and Daniels, 1992) while the decrease after calving is associated with the migration of the leucocytes towards the uterine lumen and mammary gland. Present study was also similar with Patel et al., (2017) that TLC increased significantly $(\mathrm{p}<0.05)$ from 15 days before calving till the date of calving and then decreased on 15 days after calving.

$\mathrm{Hb}$ (g/dL) ranged from 11.58 \pm 0.24 to $10.13 \pm 0.49$. This difference was statistically significant $(p<0.05)$. Significant $\quad(p<0.05)$ increase in $\mathrm{Hb}$ was found on 7 day before calving as compare to 30 and 3 day before calving. $\mathrm{Hb}$ was reduced non-significantly on the day of calving as compared to 7 day before calving. After calving $\mathrm{Hb}$ decreased nonsignificantly till 7 days of calving. At 15 days after calving significant $(\mathrm{p}<0.05)$ increase in $\mathrm{Hb}$ was found as compared to the day of calving. Stirnimann et al., (1974) reported that $\mathrm{Hb}$ concentration remained stable throughout the entire pregnancy period until two weeks after parturition, when it significantly increased as compared to values before parturition. However, Klinkon, (1993) stated that $\mathrm{Hb}$ concentration significantly increased during the $9^{\text {th }}$ month of pregnancy. Similar result was observed during this study and not found much more changes in $\mathrm{Hb}$ during peripartum period. In early lactating period showed lower $\mathrm{Hb}$, which might be due to a decreased rate of erythropoiesis in these animals (Kumar and Pachauri, 2000) or to increased $\mathrm{Hb}$ requirement of mammary tissues for milk synthesis and concomitant rise in blood flow to mammary glands (El Nouty et al., 1986).

PCV (\%) ranged from $35.65 \pm 0.70$ to $31.85 \pm 1.76$ and statistically significant $(\mathrm{p}<0.05)$. A non-significant increase in PCV was found at 7 day before calving as compared to 30 and 15 day before calving. The PCV was decreased significantly $(\mathrm{p}<0.05)$ on 3 day before calving which was increased non-significantly on the day of calving. After calving PCV reduced significantly $(\mathrm{p}<0.05)$ on 15 days post-partum as compared to the day of calving. Reynolds, (1953) reported that PCV remained stable until the last week of pregnancy when there was a marked increase and then returned to normal soon after parturition. During this study PCV had stable result observed. In the present study, the higher PCV was observed on 7 day before and on the day of parturition. It might be because of the prolonged refusal to drink water and loss of fetal fluids due to parturition. Higher PCV around immediately before calving may indicate the requirement of higher red cell volume to carry more oxygen to meet the energy requirement of tissues at the time of calving (Jain, 1986). Nazifi et al., (2008) also reported significantly higher $(\mathrm{p}<0.05) \mathrm{PCV}$ in pregnant cows just before calving as compared to postpartum period.

MCV (fL) value highest on 3 day after calving $(52.70 \pm 1.00)$ to lower at 30 day after calving $(49.83 \pm 0.60)$. On the day of calving MCV increased significantly $(\mathrm{p}<0.05)$ as compare to $30,15,3$ days before calving and $7,15,30$ days after calving. $\mathrm{MCH}(\mathrm{pg})$ ranged from 30 days before calving $(15.70 \pm 0.32)$ to 7 day before calving (16.65 \pm 0.37$)$. Highest value of $\mathrm{MCH}$ observed on 7 day before calving. Then non-significant reduction was observed on 3 day before calving and on the day of calving but significantly $(\mathrm{p}<0.05)$ decreased at 3,7 , 15, 30 day after calving as compared to highest value at 7 day before calving. MCHC $(\mathrm{g} / \mathrm{dl})$ ranged from 15 day before calving $(32.72 \pm 0.58)$ to 3 day after calving (30.67 \pm 0.26$)$. The significant $\quad(p<0.05)$ reduction observed on 3 day after calving as compared to $30,15,7,3$ day before calving. Then, MCHC increased significantly $(\mathrm{p}<0.05)$ 
at 15 day after calving. Then, significantly $(p<0.05)$ decreased on $3^{\text {rd }}$ day after calving which significantly $(\mathrm{p}<0.05)$ increased on 15 and 30 day after calving. There were no much more effect on peripartum period. Klinkon and Zadnik, (1999) reported that the periparturient period did not significantly affect the MCV, $\mathrm{MCH}$ and MCHC. It is used to find out the type of anaemia and the cause of anaemia so as to treat the animal accordingly. Gavan et al., (2010) reported that no significant differences were observed for erythrocytic indices during peripartum period but slight reduction in $\mathrm{MCH}$ and $\mathrm{MCV}$ suggest iron deficiency in animal particularly during this period.

Total Platelet Count (PLT) $\left(\times 10^{6} / \mu \mathrm{L}\right)$ of crossbred cattle ranged from 30 days before calving $(287 \pm 20.27)$ to 15 day after calving (572.33 \pm 66.89$)$. Total platelet count increased non-significantly on 3 day after calving as compared to $30,15,7,3$ day before calving and on the day of calving. The significant $(p<0.05)$ higher level was observed on 7 and 15 day after calving as compared to the day of calving. There were no any significant changes in platelet count observed during present study in peripartum period.

Lymphocyte (\%) of crossbred cattle ranged

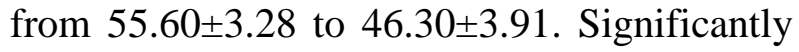
$(\mathrm{p}<0.05)$ lowest level of Lymphocyte was observed on 3 day before calving as compared to other pre calving days which was increased non-significantly on the day of calving. After parturition non-significant increase in lymphocytes was observed on 3, 7, 15 and 30 days after calving as compared to the day of calving. During present study, Lower Lymphocyte count was observed on 3 day before calving and on the day of calving. Klinkon and Zadnik (1999) observed the lower number of lymphocytes on 10 days before parturition; they were non-significantly lower than values obtained after parturition.
Pomsel, (1980) recorded significantly lower $(\mathrm{p}<0.001)$ mean absolute values of lymphocytes on the day of parturition in comparison to the first seven months of pregnancy and on the second week after parturition. The reduction in lymphocyte per cent at calving may be due to parturition stress and due to other stress hormone. Increasing level of stress hormone may be the reason for reducing the number of lymphocyte at calving (Kehrli et al., 1989).

Monocyte (\%) of crossbred cattle ranged from $4.82 \pm 0.56$ to $9.88 \pm 1.51$. Monocyte percentage was increased non-significantly till 7 day before calving which was reduced significantly $(\mathrm{p}<0.05)$ on the day of calving as compared to 7 day before calving. After parturition, significantly $(\mathrm{p}<0.05)$ higher monocyte per cent was observed on 15 and 30 days of calving as compared with the day of calving. Klinkon and Zadnik (1999) reported that the number of monocytes was constant during pregnancy in healthy dairy cows, and decreased slightly in the last month of pregnancy and during parturition. In the present study, lower number of monocyte was observed on the day of calving. It might be due to migration of monocyte from circulation to tissues and undergoes to converting macrophage to providing immunity at parturition stress.

Neutrophil (\%) of crossbred cattle ranged from $46.79 \pm 2.43$ to $36.82 \pm 0.34$ which was significant $(\mathrm{p}<0.05)$. Neutrophil per cent was increased significantly $(\mathrm{p}<0.05)$ from 30 day before calving to 3 day before calving which is the highest level of neutrophil per cent observed during the study. A slight nonsignificant reduction in neutrophil per cent was observed on the day of calving as compared to 3 day before calving. After parturition sudden significant $(\mathrm{p}<0.05)$ reduction in neutrophil per cent was found on $3^{\text {rd }}$ day after calving. 
Table.1 Mean $( \pm$ SE) values of Hematological parameters of crossbred cattle $(n=6)$ during peripartum period

\begin{tabular}{|c|c|c|c|c|c|c|c|c|}
\hline Days & $\begin{array}{c}\text { TEC } \\
\left(\times 10^{6} / \mu \mathrm{L}\right)\end{array}$ & $\begin{array}{c}\text { TLC } \\
\left(\times 10^{3} / \mu L\right)\end{array}$ & $\begin{array}{c}\mathrm{Hb} \\
(\mathrm{g} / \mathrm{dL})\end{array}$ & $\begin{array}{l}\mathrm{PCV} \\
(\%)\end{array}$ & $\begin{array}{l}\mathrm{MCV} \\
(\mathrm{fL})\end{array}$ & $\begin{array}{l}\mathrm{MCH} \\
(\mathrm{pg})\end{array}$ & $\begin{array}{l}\mathrm{MCHC} \\
(\mathrm{g} / \mathrm{dL})\end{array}$ & $\begin{array}{l}\text { Total Platelet count } \\
\qquad\left(\times 10^{6} / \mu \mathrm{L}\right)\end{array}$ \\
\hline-30 & $6.77^{\mathrm{abc}} \pm 0.18$ & $7.98^{\mathrm{bc}} \pm 0.73$ & $10.63^{\mathrm{bcd}} \pm 0.23$ & $33.65^{\mathrm{abc}} \pm 0.54$ & $49.93^{\mathrm{d}} \pm 0.99$ & $15.70^{\mathrm{d}} \pm 0.32$ & $31.57^{\mathrm{c}} \pm 0.37$ & $287.33^{\mathrm{c}} \pm 20.27$ \\
\hline-15 & $6.87^{\mathrm{ab}} \pm 0.22$ & $7.68^{c} \pm 0.60$ & $11.22^{\mathrm{ab}} \pm 0.56$ & $34.17^{\mathrm{abc}} \pm 1.16$ & $49.88^{\mathrm{d}} \pm 0.71$ & $16.25^{\mathrm{abc}} \pm 0.35$ & $32.72^{\mathrm{a}} \pm 0.58$ & $320.33^{c} \pm 21.69$ \\
\hline-7 & $6.94^{\mathrm{a}} \pm 0.08$ & $10.20^{\mathrm{a}} \pm 1.29$ & $11.58^{\mathrm{a}} \pm 0.24$ & $35.65^{\mathrm{a}} \pm 0.70$ & $51.50^{\mathrm{bc}} \pm 1.06$ & $16.65^{\mathrm{a}} \pm 0.37$ & $32.47^{\mathrm{ab}} \pm 0.35$ & $307.17^{\mathrm{c}} \pm 39.82$ \\
\hline-3 & $6.39^{\mathrm{cd}} \pm 0.24$ & $8.72^{a b c} \pm 0.75$ & $10.43^{\mathrm{cd}} \pm 0.40$ & $32.70^{b c} \pm 0.99$ & $51.33^{\mathrm{c}} \pm 0.92$ & $16.27^{\mathrm{abc}} \pm 0.28$ & $31.82^{b c} \pm 0.50$ & $309.83^{c} \pm 43.76$ \\
\hline 0 & $6.58^{\mathrm{abcd}} \pm 0.18$ & $10.05^{\mathrm{a}} \pm 1.43$ & $10.87^{\mathrm{abc}} \pm 0.44$ & $34.55^{\mathrm{ab}} \pm 1.03$ & $52.62^{\mathrm{ab}} \pm 0.93$ & $16.45^{\mathrm{ab}} \pm 0.39$ & $31.47^{\mathrm{c}} \pm 0.41$ & $300.67^{c} \pm 34.81$ \\
\hline 3 & $6.47^{b c d} \pm 0.29$ & $8.10^{a b c} \pm 1.37$ & $10.43^{\mathrm{cd}} \pm 0.45$ & $33.95^{\mathrm{abc}} \pm 1.29$ & $52.70^{\mathrm{a}} \pm 1.00$ & $16.10^{\mathrm{bcd}} \pm 0.24$ & $30.67^{\mathrm{d}} \pm 0.26$ & $379.83^{b c} \pm 44.94$ \\
\hline 7 & $6.35^{\mathrm{cd}} \pm 0.26$ & $7.62^{c} \pm 0.99$ & $10.13^{\mathrm{cd}} \pm 0.49$ & $32.58^{\mathrm{bc}} \pm 1.51$ & $51.45^{\mathrm{c}} \pm 0.92$ & $15.90^{\mathrm{cd}} \pm 0.31$ & $31.03^{\mathrm{cd}} \pm 0.30$ & $457.33^{\mathrm{ab}} \pm 67.79$ \\
\hline 15 & $6.21^{\mathrm{d}} \pm 0.30$ & $8.77^{a b c} \pm 0.59$ & $10.74^{\mathrm{d}} \pm 0.57$ & $31.85^{\mathrm{c}} \pm 1.76$ & $51.33^{c} \pm 0.99$ & $16.10^{\text {bcd }} \pm 0.28$ & $31.45^{\mathrm{c}} \pm 0.26$ & $572.33^{\mathrm{a}} \pm 66.89$ \\
\hline 30 & $6.40^{\text {bcd }} \pm 0.32$ & $8.35^{a b c} \pm 0.77$ & $10.15^{\mathrm{cd}} \pm 0.55$ & $31.87^{\mathrm{c}} \pm 1.65$ & $49.83^{d} \pm 0.60$ & $15.78^{\mathrm{cd}} \pm 0.18$ & $31.77^{b c} \pm 0.35$ & $472.33^{\mathrm{ab}} \pm 38.80$ \\
\hline Overall Mean & $6.55 \pm 0.14$ & $8.61 \pm 0.65$ & $10.63 \pm 0.23$ & $33.44 \pm 0.76$ & $51.18 \pm 0.34$ & $16.13 \pm 0.15$ & $31.66 \pm 0.25$ & $378.57 \pm 36.11$ \\
\hline
\end{tabular}

*Values having different superscripts differed significantly $(\mathrm{P}<0.05)$ within column

Table.2 Mean ( \pm SE) values of DLC of crossbred cows $(n=6)$ during peripartum period

\begin{tabular}{|c|c|c|c|c|c|}
\hline Days & $\begin{array}{c}\text { Lymphocyte } \\
(\%)\end{array}$ & $\begin{array}{l}\text { Monocyte } \\
(\%)\end{array}$ & $\begin{array}{c}\text { Neutrophil } \\
(\%)\end{array}$ & $\begin{array}{c}\text { Eosinophil } \\
(\%)\end{array}$ & $\begin{array}{l}\text { Basophil } \\
(\%)\end{array}$ \\
\hline-30 & $55.60^{\mathrm{a}} \pm 3.28$ & $5.40^{b c} \pm 0.50$ & $38.34^{b} \pm 2.42$ & $0.64^{\mathrm{b}} \pm 0.05$ & $0.03^{\mathrm{a}} \pm 0.01$ \\
\hline-15 & $50.38^{\mathrm{ab}} \pm 4.90$ & $6.90^{\mathrm{bc}} \pm 0.89$ & $41.55^{b} \pm 0.77$ & $0.79^{\mathrm{b}} \pm 0.13$ & $0.03^{\mathrm{a}} \pm 0.01$ \\
\hline-7 & $48.92^{b} \pm 4.43$ & $7.77^{\mathrm{ab}} \pm 1.11$ & $42.83^{b} \pm 0.83$ & $0.88^{\mathrm{b}} \pm 0.15$ & $0.02^{\mathrm{a}} \pm 0.00$ \\
\hline-3 & $46.30^{b} \pm 3.91$ & $6.10^{\mathrm{bc}} \pm 0.51$ & $46.79^{a} \pm 2.43$ & $0.76^{b} \pm 0.11$ & $0.02^{\mathrm{a}} \pm 0.00$ \\
\hline 0 & $48.27^{b} \pm 4.20$ & $4.82^{c} \pm 0.56$ & $45.69^{a} \pm 2.37$ & $1.20^{\mathrm{a}} \pm 0.15$ & $0.02^{\mathrm{a}} \pm 0.00$ \\
\hline 3 & $52.68^{\mathrm{ab}} \pm 3.26$ & $5.75^{b c} \pm 0.92$ & $40.71^{b} \pm 1.88$ & $0.84^{\mathrm{b}} \pm 0.11$ & $0.02^{\mathrm{ab}} \pm 0.01$ \\
\hline 7 & $50.55^{\mathrm{ab}} \pm 1.90$ & $6.13^{b c} \pm 1.17$ & $42.65^{b} \pm 1.75$ & $0.65^{b} \pm 0.09$ & $0.02^{\mathrm{a}} \pm 0.00$ \\
\hline 15 & $49.68^{b} \pm 3.87$ & $7.85^{\mathrm{ab}} \pm 1.23$ & $41.86^{b} \pm 0.90$ & $0.60^{\mathrm{b}} \pm 0.05$ & $0.01^{\mathrm{b}} \pm 0.00$ \\
\hline 30 & $52.98^{\mathrm{ab}} \pm 3.52$ & $9.88^{\mathrm{a}} \pm 1.51$ & $36.51^{b} \pm 0.34$ & $0.60^{b} \pm 0.05$ & $0.03^{\mathrm{a}} \pm 0.00$ \\
\hline Overall Mean & $50.60 \pm 3.70$ & $7.18 \pm 0.93$ & $41.89 \pm 1.52$ & $0.77 \pm 0.09$ & $0.02 \pm 0.00$ \\
\hline
\end{tabular}


Pomsel, (1980) and Kim et al., (2005) reported that neutrophil had increased by the calving period and dropped during the $1^{\text {st }}$ week postpartum. In the present study, the highest value of neutrophil was observed just before calving. Increasing level of cortisol around calving might be acting as stimulating agent for the increased neutrophil per cent around calving.

Eosinophil (\%) of crossbred cattle ranged from $1.20 \pm 0.15$ to $0.60 \pm 0.05$. Highest level of eosinophil was observed on the day of calving which is significantly $(p<0.05)$ higher as compared to other pre-partum days. After calving percentage of eosinophil was decreased significantly $(\mathrm{p}<0.05)$ on $3^{\text {rd }}$ day of calving. Thereafter level of eosinophil continuously decreased till the end of study. Schalm and Jain, (1986) reported that Pregnancy did not affect the number of eosinophils. Whereas, Pomsel, (1980) reported a decrease in the mean absolute value of eosinophils on the day of parturition and a continued decrease through the first two weeks after parturition. Eosinophil had nonsignificant changes during study entire period except on the day of calving, which increased significantly $(\mathrm{p}<0.05)$. Eosinophil had also important role to provide immunity. Due to the stress factor to provide immunity the percentage of eosinophils might be higher at the calving time.

Basophil (\%) of crossbred cattle ranged from $0.03 \pm 0.01$ to $0.01 \pm 0.00$. Basophil decreased significantly on $15^{\text {th }}$ day after calving as compared to prepartum day. Thereafter significantly $(p<0.05)$ increased on $30^{\text {th }}$ day after calving. The periparturient period did not affect the number of basophils. This finding supports work by Schalm and Jain, (1986). The present study did not reveal any significant effect of pregnancy on basophil number.
We have extracted following conclusions from this research. TEC and $\mathrm{Hb}$ increased on 7 th day before calving. Highest TLC and PCV value observed on 7th day before calving. $\mathrm{MCV}$ and $\mathrm{MCH}$ was increased significantly $(p<0.05)$ on the day of calving whereas, highest MCHC observed on 15 day before calving and significantly $(p<0.05)$ decreased on the day of calving. Highest lymphocyte count observed at 30 day before calving, whereas significant $(\mathrm{p}<0.05)$ reduction was observed on the day of calving. Highest Neutrophil count observed at 3 day before calving, which was non-significantly decreased on the day of calving. Thereafter, significant $(\mathrm{P}<0.05)$ reduction was observed till 30 day after calving. Lowest Monocyte count and higher Eosinophil count was observed on the day calving.

\section{References}

El Nouty, F.D., Hassan, G.A. andSalem, M.H. (1986) Effect of season and level of production on haematological values in Holstein cows. International Journal of Animal Science, 56, 346-350.

Gavan, C., Retea, C., and Motorga, V. (2010). Changes in the hematological profile of Holstein primiparous in periparturient period and in early to mid-lactation. Scientific Papers Animal Science and Biotechnologies, 43(2), 244-246.

Guidry, A. J., Paape, M. J., and Pearson, R. E. (1976). Effects of parturition and lactation on blood and milk cell concentrations, corticosteroids, and neutrophil phagocytosis in the cow. American journal of veterinary research, 37(10), 1195-1200.

Hussain, A. M. and Daniel, R. C. W. (1992). Phagocytosis by uterine fluid and blood neutrophils and hematological changes in postpartum cows following normal and abnormal parturition. Theriogenology, 37: 1253-1267. 
Jain, N.C., (1986). Schalm's Veterinary Hematology, (No. Edition 4) Lea and Febiger, Philadelphia, 821-837.

Junid, M., and Krad, H. (1987). Some blood values of pregnant and nonpregnant dairy cattle (Holstein-Friesian) in Syria. Monatsh veterinary Medicine, 42:700 701

Kehrli, M. J., Nonnecke, B. J., Roth, J. A., (1989). Alternations in bovine neutrophil function during the periparturient period. American Journal of Veterinary Research, 50(2): 207 214.

Kim, I. H., Na, K. J., and Yang, M. P. (2005). Immune responses during the peripartum period in dairy cows with postpartum endometritis. Journal of Reproduction and Development, 51(6): $757-764$

Klinkon, M. (1992) Red blood picture of cattle in Slovenia with regard to breed, sex, age, physiological state and rearing conditions. Dissertation, Veterinary Faculty, Ljubljana. Slovenia.

Klinkon, M. (1993) Red blood picture of cattle in Slovenia with regard to breed, sex, age, physiological state and rearing conditions. Veterinarske Novice, 19:129-139

Klinkon, M., and Zadnik, T. (1999). Dynamics of red and white blood picture in dairy cows during the periparturient period. Comparative Haematology International, 9(3), 156161.

Kumar, B. and Pachauri, S.P. (2000). Haematological profile of crossbred dairy cattle to monitor herd health status at medium elevation in Central Himalayas. Research in Veterinary Science, 69, 141-145.
Nazifi, S., Ahmadi, M. R., and Gheisary, H. R. (2008). Hematological changes of dairy cows in postpartum period and early pregnancy. Comparative clinical pathology, 17(3), 157-163.

Patel, B., Kumar, N., Jain, V., Kumar, F., HM, A., Naik, M. A., and Lathwal, S. S. (2017). Haematological status of Karan Fries cows during transition period in hot humid condition. International Journal of Science and Environment and Technology, 6, 793-797.

Pomsel, T. (1980). Hamatologische Normalwerte beim Riind in Abhangigkeit von Alter und Trachtigkeit. Berlin (Doctoral dissertation, Dissertation).

Reynolds, M. (1953) Plasma and blood volume in the cow using the T- 1824 haematocrit method. American Journal of Physiology, 173:421

Rowlands, G.J., Manston, R., Pocock, R.M. and Dew, S.M. (1975). Relationship between stage of lactation and pregnancy and blood composition in a herd of dairy cows and the influences of seasonal changes in management on these relationships. Journal of Dairy Research, 42, 349-362.

Schalm, O.W., and Jain, N.C. (1986). Veterinary haematology. Lea and Febiger, Philadelphia.

Snedecor, G. W. and Cochran, W. G. (1994). Statistical Methods. 8th edn, Iowa State University Press, Iowa.

Stirnimann, J., Stampfli, G., and Gerber, H. (1974). Eisen-und Kupfergehalt des Serums und Rotes Blutbild der Simmentaler Kuh wahrend Trachtigkeit und Puerperium. Schweizer Archive fur Tierheilkunde.

\section{How to cite this article:}

Krupa R. Joshi, M.M. Pathan, S.P. Madhira, A.M. Pande and Dhara D. Dhusa. 2018. Study of Haematological Parameters of Crossbred Cows during Peripartum. Int.J.Curr.Microbiol.App.Sci. 7(12): 461-467. doi: https://doi.org/10.20546/ijcmas.2018.712.057 